\title{
Bio-efficacy of enhanced diatomaceous earth with boric acid against Citrus mealy bug (Planococus citri).
}

\author{
M Azhar Javaid ${ }^{1 *}$, Awais Rasool ${ }^{1}$, Aqsa Yaseen $^{2}$, Zaibunissa Kokab $^{3}$ \\ ${ }^{1}$ IPMP-National Agriculture Research Center (NARC), Islamabad, Pakistan \\ ${ }^{2}$ University of Agriculture, Faisalabad, Pakistan \\ ${ }^{3}$ Sardar Bahadur Khan Women University, Quetta, Pakistan
}

\begin{abstract}
The present study was carried out to determine the bio-efficacy of Diatomaceous Earth with Boric acid against sucking pest Citrus mealy bug; Planococus citri. Three dose rates of Diatomaceous Earth with Boric acid were evaluated against the Citrus mealy bug (Planococus citri) in comparison to synthetic chemical (Bifenthrin). Diatomaceous Earth with Boric acid show the excellent mortality $81.02 \%$ on Citrus mealy bug; $3^{\text {rd }}$ instar (Planococus citri) at $30+30$ gms per liter of water; after the $\mathbf{7}$ days of application in comparison to standard chemical (Bifenthrin) at $10 \mathrm{ml}$ per liter of water.
\end{abstract}

Keywords: Planococus citri, Organic product (Diatomaceous Earth with Boric acid), Standard chemical (Bifenthrin).

Accepted May 15, 2018

\section{Introduction}

\section{Diatomaceous earth}

It is a non-toxic powder composed of fossilized, one-celled organisms called diatoms. It is used to control slugs, millipedes, sow bugs, cockroaches, ants and soft-bodied insects like aphids. It has low mammalian toxicity [1,2]. Use the "natural grade", not the type used as a filtering agent in swimming pools. Prolonged exposure to Diatomaceous Earth will irritate lungs and other tissues of people or pets. Because it also kills honeybees, avoid applying the product to crops in flower. Diatomaceous Earth products include:

- Natural Guard Diatomaceous Earth,

- Bonide Diatomaceous Earth Crawling Insect Killer,

- Natural Guard Crawling Insect Control Containing Diatomaceous Earth,

- Safer Brand Ant \& Crawling Insect Killer.

\section{Boric acid}

It is derived from boron, a naturally occurring mineral. It acts as a stomach poison and causes insects to die from starvation. Boric acid is available in powder, paste, aerosol, tablet, and liquid forms for use against cockroaches, ants, and other insects. It should not be applied around plants in the landscape because, although boron is a necessary plant micro-nutrient, larger than trace amounts are toxic to plants $[3,4]$.

Most Boric acid products are available as ready-to-use products. Boric acid (labels may list this as Orthoboric acid or sodium tetraborate) is sold under a number of brand names, including:

- Terro Outdoor Liquid Ant Baits,

- Pic Boric Acid Roach Killer Gel,

- Pic Ant Killing System (Bait),
- Terro Multi-Purpose Insect Bait.

\section{Bifenthrin}

Bifenthrin is a pyrethroid insecticide used to control a range of pests. It has a low aqueous solubility and is volatile. There is a low risk of groundwater contamination based on its chemical properties and it is not persistent in soil. There are some concerns about bioaccumulation and the pesticide shows a high oral toxicity to mammals as well as being an endocrine disrupter and a neurotoxicant [5,6]. It is toxic to birds, most aquatic organisms, honeybees and earthworms. A pyrethroid is acaricide/insecticide use in a wide range of crops to control sucking and biting foliar pests.

Pakistan has several varieties of citrus fruit, in addition to the popularity known as kino all of which may interest importer in Asia and Europe. Kino is rightly called the king of easy peelers and excels the best varieties of the world. Citrus juice contest $44 \%$ to $47.5 \%$ which is the highest easy peeler varieties. Sugar content is 12 to $13 \%$ and each $100 \mathrm{ml}$ of kino contain $20 \mathrm{mg}$ to $25 \mathrm{mg}$ of Vitamin C. Pakistan produce kino 80\%. In Pakistan citrus fruit is important fruit crop grown the area of 206,569 hectares with the production of 2.5 million tones.

The pest is a native of Asia but is also found throughout the Americas, Europe, and Oceania. In North America, it is present in both Mexico and the United States (Alabama, Arizona, Arkansas, California, Florida [7,8] Hawaii, Kansas, Louisiana, Maryland, Massachusetts, Missouri, New Mexico, Ohio, South Carolina, Tennessee, Texas, and Virginia) (CABI/EPPO 1999) (Figure 1).

Although there are no documented cases of insecticide resistance associated with either citrus mealy bug or long tail mealy bug, resistance has been reported with other mealy bugs in the genera, Planococcus and Pseudococcus [9]. The citrus mealy bug, Planococcus citri (Risso) (Hemiptera: Pseudococcidae) attacks many host plants including all orchard trees in Egypt. Citrus 
mealy bug and long tail mealy bug have similar life cycles except that long tail mealy bug are ovoviviparous (females give birth to live in stars, whereas citrus mealy bug are oviparous (females lay eggs). Female mealy bugs have five life stages; egg, three instars, and adult [10,11]. Citrus mealy bug (CM) is a polyphagus pest of citrus orchards and nurseries [12]. It has a wide host range of different citrus species and other fruit trees in subtropical and tropical areas [13]. The nymph stage and adult female cause damage to the trees [6].

Chemical insecticides can have adverse effects on the environment and human health and can induce insecticide resistance in the target pest species and kill beneficial insects [5]. Chemical insecticides, to control citrus mealy bug and since the second and third instar nymph is covered with white-cottony wax and has a fringe of elongated waxy filaments that extends about the periphery of the body consequently [14], it is quite difficult to control citrus mealy bug [15].

Citrus mealy bug and long tail mealy bug males undergo six life stages and become winged adults [16,17]; Direct damage to plants results in stunting, yellowing of leaves, leaf drop, increased risk of infection by plant pathogens, and occasionally plant death [6,16-21]. Mealy bugs are polyphagous insects that feed within the vascular tissue of plants using their piercingsucking mouthparts, to withdraw plant fluids [17,18]; Indirect damage is caused by the excretion of honeydew [11,22,23], a clear sticky liquid that is an ideal growing medium for black sooty mold fungi, which can reduce the ability of plants to photosynthesize $[18,19]$. Also, honeydew is a supplemental food source for ants which may protect mealy bugs from biological control agents or natural enemies such as parasitoids or predators $[16,24]$. This observation may have led the Chinese to use Diatomaceous Earth (diatomite) for pest control 4000 years ago [2].

\section{Materials and Methods}

The stock culture of citrus mealy bug was originally collected from NARC citrus orchard. The mealy bug colony was kept under laboratory conditions of $25 \pm 2^{\circ} \mathrm{C}, 60-70 \% \mathrm{RH}$ on pumpkin fruits and potato sprouts as host plant of citrus mealy bug showed in Figure 2.

Pumpkin and Potatoes are washed with tap water and air-dried. Then Potatoes are placed in boxes and cover with black cotton cloth to encourage sprouting. Boxes were kept in dark place at $27^{\circ} \mathrm{C}$ and $65-75 \% \mathrm{RH}$. When potato sprouts reached to $2 \mathrm{~cm}$ $3 \mathrm{~cm}$ in length. Then sprouts were shifted into rearing box for the culture of citrus mealy bug. Eggs were taken from the isolated adults; females immediately after deposition and placed on potato sprouts and pumpkin to maintain the colony. Every week, newly sprouted potatoes were added to the stock culture of $P$. citri to maintain the colony $[25,26]$.

Prepared 15 Petri dishes by cutting the filter paper equal to the size of Petri dishes and placed the filter papers in Petri dishes. Then fine potato sprouts were placed into Petri dishes and finally released ten $3^{\text {rd }}$ instar insects of citrus mealy bug in each Petri dish and were sprayed (Figure 3). Each Petri dish was placed under controlled condition $\left(25^{\circ} \mathrm{C}, \mathrm{RH} 60 \%\right)$. The experiment was laid under Randomized Complete Block Design (RCBD) with 5 treatments including control while all the treatments were replicated thrice. Mortality data was recorded after 3 days; 5 days and 7 days of post treatment $[5,9,27]$.
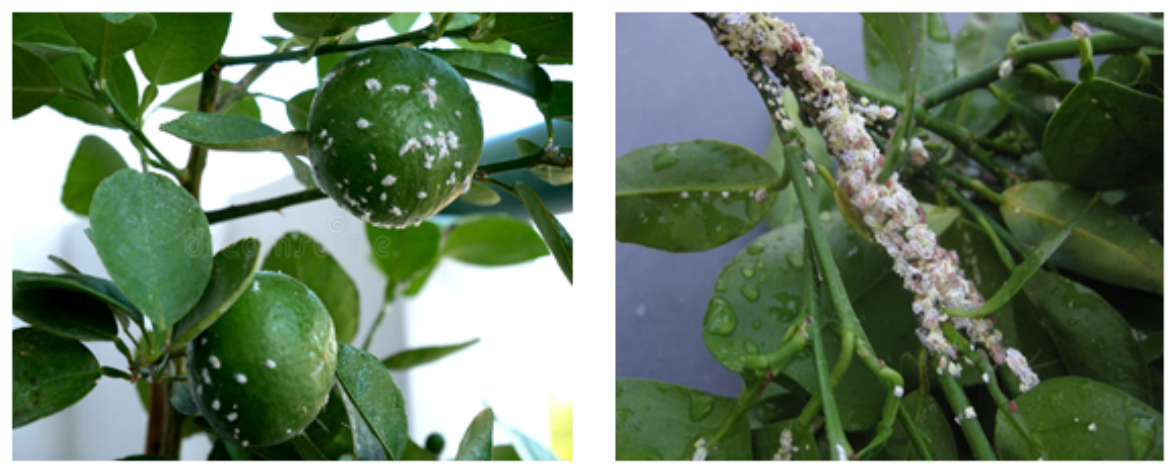

Figure 1. Plants affected by Citrus Mealybug.

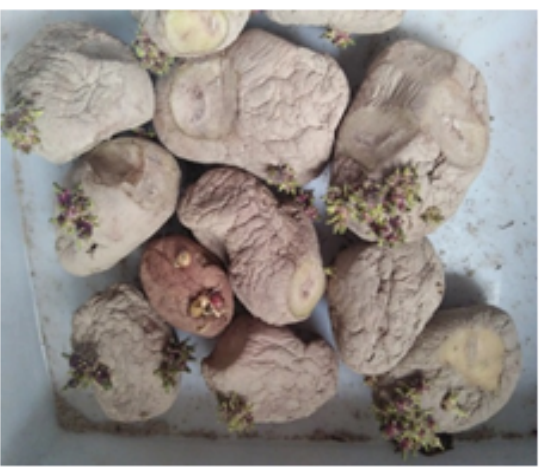

Potato Sprouts

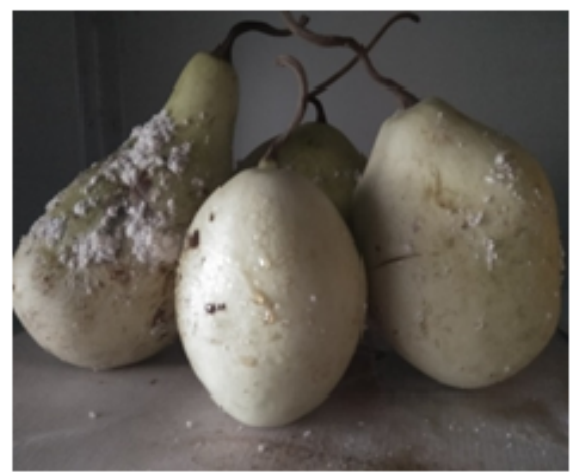

Pumpkins fruits

Figure 2. Images of Potato Sprouts and Pumpkin fruits. 
In order to determine toxicity of insecticides at their recommended field doses, Bifenthrin, Boric acid and Diatomaceous Earth against the $3^{\text {rd }}$ instar were sprayed by lady hand sprayer (Figure 4) with the solutions prepared in $1000 \mathrm{ml}$ of distilled water. The check / control were sprayed with distilled water only.

Abbots formula (Flemings and Ratnakaran 1985) was used for percent population change which is as under;

$$
\% \text { population change }=1-\frac{\begin{array}{c}
\text { post treatment population } \\
\text { !pretreatment population } \\
\text { intreatment }
\end{array}}{\text { npretreatment population }}
$$

Calculated \% mortality was analyzed by [RCBD] variance and means and transformed averages were used at 5\% and $1 \%$ level.

\section{Results and Discussion}

The results of the preliminary assessment of the study area found that the Citrus Mealy Bug (Planococus citri) infestation remains the same in control up to 7 days. In order to reduce the infestation level of the Citrus Mealy Bug (Planococus citri) through D+B and to see comparison of synthetic product Laboratory study was determined. Highly significant differences among the treatments were observed after the application of $\mathrm{D}+\mathrm{B}$ and the results are depicted in Table 1 and Figure 5. After 7 days of spray; treatments 3 and 4 shows significantly very good mortality of Citrus Mealy Bug (Planococus citri); in comparison to control and the trend of Citrus Mealy Bug (Planococus citri) population decrease observed up-to 7 days. D+B at $30 \mathrm{gms}$ per liter of water gave $81.02 \mathrm{~b} \%$ mortality; almost equal to synthetic insecticide Talstar-10EC (Bifenthrin) and D+B at 10 and 20 gms per liter of water gave $54.63 \mathrm{~d} ; 68.98 \mathrm{c} \%$ mortality; was significantly less at both cd $5 \& 1$ percent by means of IPM/Organaic management of Citrus Mealy Bug (Planococus citri) $3^{\text {rd }}$ instar populations after 7 days of spray in comparison to standard chemical used. The use of $\mathrm{D}+\mathrm{B}$ at 30 gms per liter of water can play important role to produce certified organic production of Citrus in Pakistan (Table 1).

\section{Conclusion}

Diatomaceous Earth with Boric acid is the alternative of chemicals/pesticides; which has managed Citrus Mealy Bug (Planococus citri) in the laboratory at $30+30$ grams in one liter

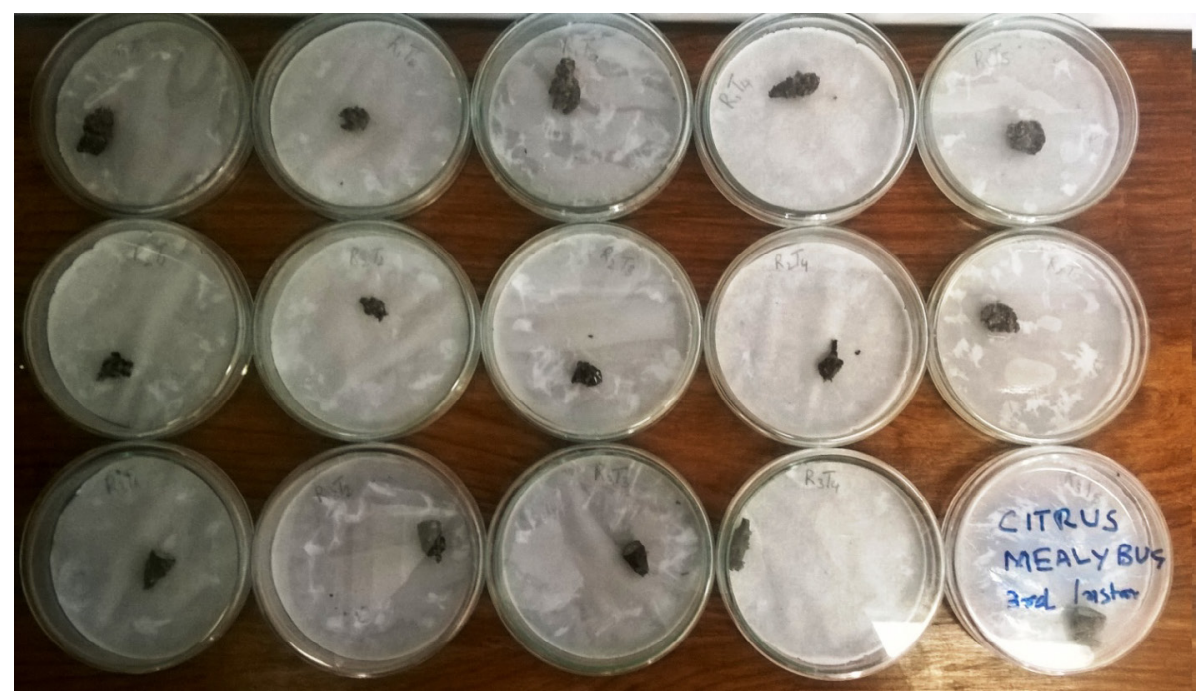

Figure 3. Experimental treatments.

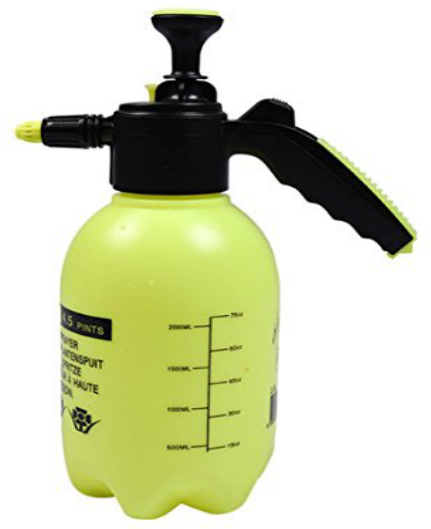

Figure 4. Lady hand sprayer.

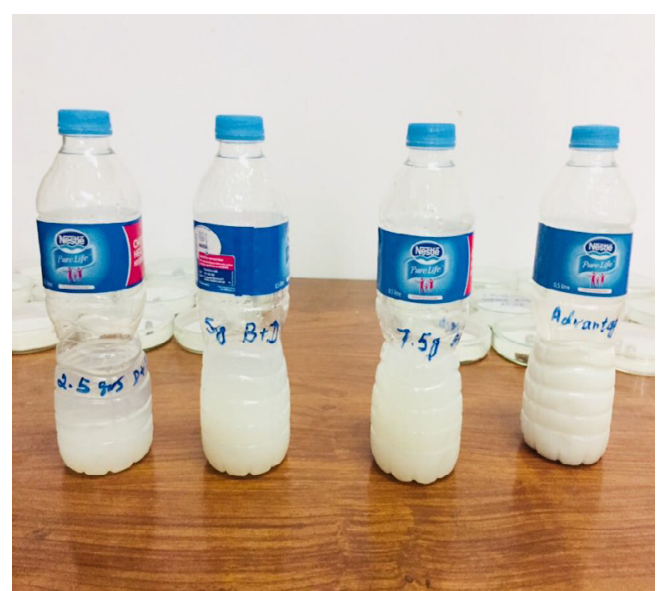

Figure 5. Treatment solutions. 
Citation: Javaid MA, Rasool A, Yaseen A, et al. Bio-efficacy of enhanced diatomaceous earth with boric acid against Citrus mealy bug (Planococus citri). J Agric Sci Bot. 2018;2(2):29-33.

Table 1. \% mortality of $3^{\text {rd }}$ Instar of Citrus Mealy Bug (Planococus citri).

\begin{tabular}{|c|c|c|c|c|c|c|c|c|c|}
\hline $\begin{array}{l}\text { Brand } \\
\text { name }\end{array}$ & Chemical name & $\begin{array}{c}\text { Dose (Rate/Liter } \\
\text { of water) }\end{array}$ & $\begin{array}{l}\text { Population } \\
\text { Before spray }\end{array}$ & $\begin{array}{l}\text { Population } \\
\text { After } 3 \text { Days }\end{array}$ & $\begin{array}{l}\text { Population } \\
\text { After } 5 \text { Days }\end{array}$ & $\begin{array}{l}\text { Population } \\
\text { After } 7 \text { Days }\end{array}$ & $\begin{array}{l}\% \text { Mortality } \\
\text { After } 3 \text { Days }\end{array}$ & $\begin{array}{l}\% \text { Mortality } \\
\text { After } 5 \text { Days }\end{array}$ & $\begin{array}{c}\text { \% Mortality } \\
\text { After } 7 \text { Days }\end{array}$ \\
\hline$D+B$ & $\begin{array}{l}\text { Diamataceous Earth } \\
\text { + Boric Acid }\end{array}$ & $10+10 \mathrm{gms}$ & 10 & 9 & 7.33 & 4 & -3.7 & 16.2 & $54.63 d$ \\
\hline$D+B$ & $\begin{array}{c}\text { Diamataceous Earth } \\
+ \text { Boric Acid }\end{array}$ & $20+20 \mathrm{gms}$ & 10 & 8.66 & 5.66 & 2.66 & 0.46 & 34.72 & $68.98 \mathrm{c}$ \\
\hline$D+B$ & $\begin{array}{l}\text { Diamataceous Earth } \\
\text { + Boric Acid }\end{array}$ & $30+30 \mathrm{gms}$ & 10 & 8.66 & 4.33 & 1.66 & 0.46 & 50.46 & $81.02 b$ \\
\hline Talstar & Bifenthrin & $10 \mathrm{ml}$ & 10 & 0 & 0 & 0 & 100 & 100 & $100.00 a$ \\
\hline \multirow[t]{3}{*}{ Check } & - & - & 10 & 8.66 & 8.66 & 8.66 & - & - & \\
\hline & & & & & & & 7.48 & 9.3 & \\
\hline & & & & & & & 11.33 & 14.08 & \\
\hline
\end{tabular}

Transformed averages of \%mortality are used in ANOVAs.

$\mathrm{D}=$ Diatomaceous Earth; $\mathrm{B}=$ Boric acid; $\mathrm{Cd}=$ Critical difference

of water formulation (30 grams of Diatomaceous Earth+Boric acid). The efficacy was slow due to organic properties of both compounds vs. chemical bifenthrin. This study proved statistically as good as chemicals against Citrus Mealy Bug (Planococus citri); in comparison to untreated/control; which is cheaper in price; easy to prepare; environment friendly and can promote organic citrus for premium profits and IPM techniques.

\section{References}

1. Abrams HK. Diatomaceous Earth Pneumoconiosis. Am J Public Health. 1954;44:592-9.

2. Allen F. A natural earth that controls insects. Organic gardening and Farming. 1972;19:50-6.

3. Brattsten LB, Holyoke CW, Leeper JR, et al. Insecticide resistance: challenge to pest management and basic research. Science 1986;231:1255-60.

4. Bivins JL, Deal AS. Systemic insecticides for control of Citrus mealybug in gardenias. California Agriculture. 1973;27(8):5-6.

5. Damavandian MR, Hashemi T. The effect of pre spring control on the population of the citrus pest research letter of Agricultural Sciences. 2005.

6. Goldasteh SH, Talebi AA, Fathipour Y, et al. Effect of temperature on life history and population growth parameters of Planococcus citri (Homoptera, Pseudococcidae) on coleus (Solenostemons cutellarioides (L.) Codd.). Arch Biol Sci Belgrade. 2009;61(2):329-36.

7. Abbas G, Arif MJ, Saeed S. Identification of mealy bug as the novel pest of cotton In Pakistan. Proceedings of the $34^{\text {th }}$ SAARC Science Conference. 2006;31:20-2.

8. Ahmed NH, Abd-Rabou SM. Host plants, geographical distribution, natural enemies and biological studies of the citrus mealy bug, Planococcus citri (Risso) (Hemiptera: Pseudococcidae). Egyptian Academic J Biol Sci. 2010;3:39-47.

9. Whalon MD, Mota-Sanchez R, Hollingworth, et al. Arthropod pesticide resistance database. Michigan State University. 2012.

10. Clausen CP. Mealybugs of citrus trees. California Agricultural Experimental Station Bulletin, College of
Agriculture, University of California, Riverside, CA. 1915;258:19-48.

11. Franco JC, A Zada, Z Mendel. Novel approaches for the management of mealy bug pests, pp 233-278. In: Biorational Control of Arthropod Pests, I. Ishaaya and A. Horowitz (eds.). Springer Science and Business Media B.V. 2009.

12. Rung A, Miller D, Scheffer S. Polymerase Chain Reaction Restriction Fragment Length Polymorphism Method to Distinguish Three Mealybug Groups Within the Planococcus citri-P. minor Species Complex (Hemiptera: Coccoidea: Pseudococcidae). J Econ Entomol. 2009;102(1):8-12.

13. Carter W. Geographical distribution of mealy bug wilt with some other insect pest of pineapple. J Econ Entomol. 1942;35:10-5.

14. Ebeling W. Physicochemical mechanisms for the removal of insect wax by means of freely divided powders. Hilgardia. 1961;30:531-64.

15. Saboori A, Hosseini M, Hatami IB. Preference of adults of Allothrombium pulvinum Ewing (Acari: Trombidiidae) for eggs of Planococcus citri (Risso) and Pulvinariaauranti Cockerell on citrus leaves in the laboratory. Syst Appl Acarol. 2003;8:1-6.

16. McKenzie HL. Mealybugs of California with taxonomy, biology and control of North American species. University of California Press, Berkeley and Los Angeles, CA. 1967.

17. Cloyd RA, RK Lindquist. Section 3: Insect and mite pests. In: Tips on Managing Problems in Interior Plantscapes. O.F.A. Services Inc., Columbus, OH. 2001.

18. Kosztarab M. Scale Insects of Northeastern North America: Identification, Biology, and Distribution, Virginia Mus Nat Hist. Special Publication No.3, Martinsville, VA. 1996.

19. Manaker GH. Interior plantscapes: Installation, maintenance, and management. 3rd ed. Prentice-Hall, Upper Saddle River, NJ. 1997.

20. Bartlett BR. Biotic factors in natural control of citrus mealy bugs in California. J Econ Entomol. 1957;50:753-5.

21. Muma MH. Ladybeetle predators of mealy bugs. Citrus Magazine. 1954;16:16-7. 
22. Gray HE. The development of the citrus mealy bug. J Econ Entomol. 1954;47:174-76.

23. Kurdyukov VV, Alan MN. Damage caused by citrus mealy bug, Pseudococcus citri [on grapevines] and its chemical control. Byulleten' Vsesoyuznogo Nauchno Issledovatel'skogo Instituta Zashchity Rastenii, No. 26. 1973;26-30.

24. Kole M, Hennekam M. Update: six years of successful biological control in interior plantscapes in The Netherlands. IPM Practitioner. 1990.
25. Martinez MDlA, M Suris. Developmental variations of Planococcus citri using potato tuber as an alternative substrate. Rev Protect Veget. 1987b;2(2):130-33.

26. Speare AT. Natural control of the citrus mealybug in Florida. U.S. Department of Agriculture Bulletin. $1922 ; 1117: 18$

27. Watson JR. Insects of a citrus grove. University of Florida Agricultural Experiment Station Bulletin. 1918;148:214-6.

\section{"Correspondence to:}

M Azhar Javaid

IPMP-National Agriculture Research Center (NARC) Islamabad, Pakistan

E-mail: azharjavaid359@yahoo.com 